\title{
Black Elitism and Cultural Entrepreneurship in 1920's Boston, Massachusetts: The League of Women for Community Service
}

\section{Craig Doughty}

\section{(2) OpenEdition Journals}

Electronic version

URL: https://journals.openedition.org/ejas/14728

DOI: 10.4000/ejas.14728

ISSN: 1991-9336

\section{Publisher}

European Association for American Studies

Electronic reference

Craig Doughty, "Black Elitism and Cultural Entrepreneurship in 1920's Boston, Massachusetts: The League of Women for Community Service", European journal of American studies [Online], 14-2 | 2019, Online since 09 July 2019, connection on 08 July 2021. URL: http://journals.openedition.org/ejas/ 14728 ; DOI: https://doi.org/10.4000/ejas. 14728

This text was automatically generated on 8 July 2021.

Creative Commons License 


\title{
Black Elitism and Cultural Entrepreneurship in 1920's Boston, Massachusetts: The League of Women for Community Service
}

\author{
Craig Doughty
}

1 In her 1994 study, The Other Brahmins: Boston's Black Upper Class, 1750-1950, Adelaide Cromwell acknowledges the existence of class differences in Boston, placing emphasis on a small black upper-crust. These people, consisting of business professionals, clerks, teachers, caterers, and small merchants had moderate wealth, were college educated, attended churches, and had some standing in community matters. ${ }^{1}$ Amongst this small collective was a group of upwardly mobile African-American females, who functioned under the group heading of the League of Women for Community Service (LWCS). ${ }^{2}$ This group pursued their own advancement through community activities in the arts, incorporating the tastes, organisational practices and aesthetic sensibilities of Boston's Anglo-American cultural elites, the Brahmins. In doing so, they sought to advocate and promote a brand of high culture stewardship that, as Paul DiMaggio states, equated to 'black cultural capitalism', albeit within a context of rigid racial boundaries during an era of widespread discrimination. ${ }^{3}$ In the process of promoting an aesthetic hierarchy of distinction, the LWCS excluded the black the working class and poor and rejected mainstream musical forms, including Jazz and the Blues. This article explores the impact of black cultural entrepreneurship on black uplift within the developing social, cultural, and political landscape of early twentieth century Boston.

\section{Introduction}

2 The leaders of black political, social, and cultural movements across America throughout the first half of the twentieth century were primarily men. The influence of Booker T. Washington, W.E. B. DuBois, and James W. Johnson and others was great and 
has been widely documented. These men were culturally driven; they were civil rights activists intellectually mobilised for the justice and the equality of all blacks. But as William B. Gatewood noted, as influential as the black male aristocracy was in Boston, it was their wives who dominated the social etiquette and taste preferences of the black elite for many decades. ${ }^{4}$ In particular, the League of Women for Community Service (LWCS), established in 1918 was the leader of black cultural conventions for much of the nineteen-twenties.

3 The LWCS emerged out of the social reformist spirit of the black women's club movement of the 'Women's Era' (1880-1920), serving as a community comfort group during the First World War. ${ }^{5}$ In this respect, they provided much needed assistance to returning soldiers and bereaved wives. Post-1918, as the need for community comfort eased, the LWCS diversified and began to assist blacks in the quest to achieve social uplift. Through public engagement, they sought to advance black education and the arts by organising concerts, lectures, seminars, and exhibitions that showcased black creativity in the city with the aim of inspiring the wider black community, but also aimed at counteracting negative perceptions of black culture principally held by whites.

4 While the arts and cultural enterprise were gateways to social uplift for blacks in many American cities - for example, the Harlem Renaissance showcased a vibrant cultural movement that redefined black music, theatre, and the visual arts - the LWCS differed because they pursued racial uplift by appropriating and appealing to white cultural sensibilities and taste preferences-in particular, those of the Brahmin class. The Brahmins were Boston's elite, Anglo-American, figures of power. ${ }^{6}$ With their New England exclusivity, close ties to Harvard University, and staunch Puritanism, the Brahmins were the rich, the well-born, and the powerful and they had dictated political, social, economic, and cultural interests in Boston for over a century and their heritage was well established.

5 However, despite their wealth and standing, families including the Appletons, the Cabots, the Codmans, the Coolidges, the Lodges, and the Lowells were not lavish or wasteful. They promoted age-old mantras of charity, humility and an adherence to modesty, even going as far as to advocate frugalness. Moreover, the adages of hard work, culture and education were central to the Brahmin way of life. They maintained a legacy of staunchness based on historic accomplishments; i.e., if it used to be done this way, it ought to be done this way, and, by God, it will be done this way. In this respect, one might ask how many Boston Brahmins does it take to screw in a lightbulb? The Answer would be ten: one to put in the new bulb, and nine to reminisce about how great the old one was.

6 As patrons of the arts and wealthy philanthropists centrally located to Boston's power structure, both literally and figuratively, the Brahmins endowed the city in the second half of the nineteenth century with theatres, concert halls, and museums, including The Athenaeum, the Peabody Essex, Boston Symphony Hall, the Museum of Fine Art, and the Isabella Stewart Gardner Museum. ${ }^{7}$ These institutions, which rivalled some of the finest in Europe, gave Boston a certain cultural distinction. In particular, they served to provide the city with a classical and Eurocentric canon of legitimate highculture. Emphasis in this respect was placed on concert and symphony music, notably chorales, oratorios, and operatic airs. 
7 By the turn of the twentieth century, aided by the industrial revolution and the subsequent creation of a defined middle-class in America, many white Bostonians found themselves beneficiaries of a new economic power. With greater wealth and more importance placed on the advantages of leisure time, the Brahmins took full charge of the baton they had shared with intellectuals and hymnodic reformers for much of the nineteenth-century and transformed culture into a form of capital. The Boston Symphony Orchestra, in a concert programme from 1967, reminiscing about its rise remarked:

The industrial Revolution was fostering bourgeois communities. The prosperous tradesman, or more probably his wife, was found cultivating the arts. There began to accumulate a new phenomenon in the Western World-a potential concert public, a public in complete contrast to the social gatherings in the mansions of Vienna or Paris. ${ }^{8}$

The city embraced the music of Hector Berlioz, and later Brahms and Wagner - artists who were able to convert standard orchestral forms into canvases for abstract, vanguard expression that pushed the limits of performers, instruments, performance spaces, and the tastes of audiences.

The LWCS's adoption and appropriation of the Brahmin approach to philanthropy, education, and culture set them apart from many black social and cultural cliques of the time. Their advocation and promotion of a nuanced brand of high-class cultural stewardship equated to what Crystal M. Fleming and Lorraine E Roses refer to as 'black cultural capitalism'; terminology synonymous with Paul DiMaggio's concept of the institutionalised cultural capitalism propagated by the Boston Brahmins during the eighteenth century: an approach to culture rooted in a sense of group consciousness and collective identity that served as an economic resource for the financial and material support of enterprises ultimately aimed at the advancement of an entire group..$^{10}$

However, the LWCS were not nearly as financially advantaged, socially connected or as influential as their white counterparts. The Brahmins were centrally located at the heart of Boston's power structure. In contrast, the LWCS existed on the periphery. As such, they were much more constrained in their ability to redefine the cultural field. Whereas the Brahmins successfully institutionalised their aesthetic sensibilities, the LWCS were limited in the symbolic and material resources they had at their disposal. Where the Brahmins could convert economic and social capital into durable cultural institutions, the LWCS were much more likely to bring about change through coalition building and, more infrequently, strategic partnerships with dominant Brahmins.

11 Drawing from archival records (meeting minutes and correspondences), historical documents (local news coverage) and biographies, this article focuses on the formative years of the LWCS, 1919 - 1923. In particular, attention here is on the ways that the LWCS appropriated, incorporated and on occasion diverged from the organisational practices and aesthetic sensibilities of the Boston Brahmins to cultivate a black sphere of high art. Insofar as the LWCS's work was principally embedded in the objectives of social mobility for blacks in the city, their efforts to generate uplift relied upon their adherence to the cultural capitalist precept. Notably, they aspired to develop and thereafter perpetuate a sophisticated field of black artistry within the adopted framework of Eurocentric norms that had, similarly, been established by the Brahmins. 


\section{Josephine Saint Pierre Ruffin and The Women's Era Club: 'Help to make the world better.'11}

12 Studies of black communities in the late nineteenth and early twentieth centuries acknowledge the existence of class differences in America. In his 1899 study, The Philadelphia Negro, W.E.B. DuBois noted the presence of what he defined as a small upper class of blacks, which included caterers, government clerks, teachers, professionals, and small merchants..$^{12}$ Many of these individuals had significant wealth, elite education, political influence, and connections. ${ }^{13}$ Similarly, Adelaide Cromwell in her work The Other Brahmins: Boston's Black Upper Class, 1750-1950 notes comparable professional trends in Boston, adding that the black upper class during the period in question belonged to an upper crust that was principally college-educated, attended churches, and included community leaders. ${ }^{14}$

William B. Gatewood remarked that 'Boston's black upper class had a reputation for black exclusiveness that went beyond the refinement of comparable groups in more established black centres of the time, such as Washington and Philadelphia'. ${ }^{15}$ From the mid-nineteenth century onwards, wealthy black men, including merchant, John $\mathrm{H}$. Lewis and the Baker, Joseph Lee assisted in promoting old-line black families of less means in Boston like the Ruffins, Ridleys, Duprees and Haydens. For example, George L. Ruffin, a Harvard-educated attorney, legislator, city judge and noted loyal Republican in time became one of the most respected lawyers in New England in the late nineteenth century; ${ }^{16}$ and by the time of his death on November 201886 of Bright's disease, he had amassed more white clients than black. ${ }^{17}$

The black upper class in Boston established a genteel way of life that extended to the employment of white servants, musical training for their children, and membership into high-class associations that were modelled on those of their white counterparts. William H. Dupree was a prominent fixture in Boston's upper-class and a militant on racial matters. He was also in charge of the city's largest postal sub-station alongside his brother-in-law, William Monroe Trotter. Trotter, himself a civil rights activist, also served as a newspaper editor and real estate businessman. ${ }^{18}$ His son, James Monroe Trotter studied at Harvard, ${ }^{19}$ graduated magna cum laude, and thereafter became an influential newspaper editor, a real estate businessman and, like his father, a prominent Civil Rights activist. ${ }^{20}$ The baton of success was ultimately shared and eventually passed on to future generations.

In 1893, Josephine Saint Pierre Ruffin, wife to George L. Ruffin, was working as the editor for the Boston Courant, a weekly 'Negro newspaper' founded three years prior. The Courant serviced the interests of a small black population of 8,125 ( $2 \%$ of the city's total population) during a time when the Great Migration had fractured race relations. ${ }^{21}$ The newspaper functioned as a mouthpiece for the black struggle in Boston. Throughout its five years of publication, the Boston Courant regularly published work that supported the pursuit of equal rights, including W. E. B. Du Bois' early Harvard Daily Themes and classroom papers. ${ }^{22}$ His writings aired dissatisfaction with America's racial policies, which were considered discriminatory and restrictive. ${ }^{23}$

16 Through connected channels, including the influence of her husband, Saint Pierre Ruffin founded the Women's Era newspaper in 1894. It was billed as the first national newspaper published by and for black women. ${ }^{24}$ As the paper's editor and publisher, 
Ruffin shaped the Women's Era into a platform for the promotion of women's suffrage, black female activism, and general interest-social etiquette, exercise, and health and beauty. ${ }^{25}$ There were also regular interviews with prominent black female activists such as Victoria Earle Matthews and Ida B. Wells; ${ }^{26}$ and a series of articles entitled 'Eminent Women' that included a praiseworthy profile of Harriett Tubman. Ruffin also courted controversy by criticising those she felt were not doing enough for the black cause, including the city judge, Albion W. Tourgée, who took a particularly nuanced approach to stopping lynching:

In his very admirable and searching address delivered in this city, April 16th, judge Albion W. Tourgee proposed as a remedy to prevent the lynching of colored people at the South, that the country where lynchings occur be compelled by law to pension the wife and children of the murdered man. This, he said would make murder costly and in self defense the local authorities would put a stop to it. At first blush, this is an attractive suggestion. But why not hang the murderers? Why make a distinction between the murderers of white men and the murderers of colored men? ${ }^{27}$

17 The broader aim of the Women's Era was to supplement the Women's Era Club (The WEC). Founded in 1892 by Ida B. Wells-Barnett, the WEC was the first black women's civic association in America and the driving force behind the National Federation of African-American Women, which comprised representatives of other groups from across the country. At its core, the WEC was philanthropic and promoted temperance and moral reform. The Club comprised a small membership of around 130 members that met twice monthly and paid annual dues of one dollar. ${ }^{28}$ Funds raised serviced scholarships, the holding of classes in civics, domestic science, literature, the sponsorship of kindergartens, hospitals and the organising of clinics among other activities. ${ }^{29}$ Through the reportage of these activities, Boston's black women, and those they came to inspire further afield, felt a special calling for racial uplift. ${ }^{30}$

18 The Women's Era and The Women's Era Club showcased the existence of a 'growing class' of intelligent, cultured black women sharing the aims of 'all good, aspiring women' in Boston; and by this 'dignified showing' they sought to refute charges of ignorance and immorality levelled at blacks outright, particularly by the American press. Mary Church Terrell wrote that members:

have determined to come into the closest possible touch with the masses of our women, through whom the womanhood of our people is always judged. ${ }^{31}$

19 The WEC reified its aims by aligning their practical approaches to community service with those of their white counterparts. In late nineteenth century Boston, white women of class, backed by their husbands including Julia Duff and Emily Fifield, garnered respect for their participation in practices such as scholarship, reform, social work, and gendered politics-notably inside the parameters of the Boston School Committee. ${ }^{32}$

Scholars of black women's history, including Katie Canon, have used the term 'womanist' to capture the distinctive elements of political action employed during the period in question and to distinguish black reform politics and movements across America from those of middle-class white women. ${ }^{33}$ Insofar as there are obvious distinctions to be drawn between the women in question, they did to differing degrees all utilise the influence of their husbands and worked along the lines of class-affinity in the spheres of scholarship, reform, social work and gendered politics. The main difference lies in the aims of these women. Duff and Fifield pushed against one another 
within the boundaries of white hegemony and Yankee Protestantism and Unitarianism to appropriate the Boston School Committee in their respective images.

In contrast, Josephine St. Pierre Ruffin and the Women's Era Club had a broader remit. They used class-affinity in predominantly black-centric spheres of scholarship, reform, and social work to target racial barriers both locally and nationally to promote unity and counteract racial inferiority. ${ }^{34}$ Locally, Ruffin subsequently became a founder of the Association for the Promotion of Child Training in the South of Boston branch of the National Association for the Advancement of Colored People, nurturing an aspirational mindset in young blacks; while nationally in 1896, the National Federation of AfroAmerican Women merged with the Colored Women's League to form the National Association of Colored Women. Ruffin was elected as vice president. ${ }^{35}$ In this capacity, she came to embody a nationwide movement led by women of colour for the benefit of women and men of colour. ${ }^{36}$

In 1918, assisted by Maria Baldwin, Saint Pierre Ruffin founded the League of Women for Community Service (LWCS). As an organisation, the LWCS was made up of a collective of well-connected and culturally aware women of experience in matters of race, education and the arts. Several of its members, Pierre Ruffin and Baldwin included, were older-line women with established roots in the community: Elizabeth Harley Forbes, Mrs Florida Ruffin Ridley, and Maud Cuney Hare. ${ }^{37}$ Baldwin was the serving principal of the well-known, predominantly white Agassiz Grammar School in Cambridge, Massachusetts. She was one of the few black women to head such a northern school, and she oversaw an all-white staff of twelve and a pupil body of 500: $98 \%$ white. This not only defied the social hierarchy of the time but also highlighted the ability of Baldwin to work in inter-racial alliance with whites and where necessary to have the wherewithal to lead them..$^{38}$

To begin, the LWCS served the war effort on a local basis, and their activities mirrored those of Brahmin women, who had themselves taken to comfort work and fundraising a year earlier. Brahmins, including the Leiters, Rantouls, and Bradleys served the needs of returning soldiers in their respective locales. ${ }^{39}$ Many, however, had family or social connections in Europe and demonstrated their influence and financial power by extending their charitable work to them. There was fundraising such as classical musicales in support of the French wounded and Polish sufferers, and a mid-July fair held in support of the Navy YMCA. ${ }^{40}$ These events demonstrated the Brahmins' sense of noblesse oblige, which manifested itself through the intertwining of social (cultural) activities with good causes while simultaneously showcasing their far-reaching influence.

24 As the need for comfort services waned after World War I, the LWCS initially remained functional by running a daily soup kitchen. ${ }^{41}$ Staffed by volunteers and supplemented by donations, the kitchen served the needs of 'two hundred little boys of all races and creeds', assisted new mothers, providing guidance and childcare, and in conjunction with the National Civic League, distributed luncheons to under-financed Boston schools. ${ }^{42}$ In doing so, the LWCS remained connected to their roots and adhered to the general practices of other female-led non-profit community groups in Boston, such as 'The Women's Service Club' and 'The Hattie B. Cooper Community Centre'. Both organisations undertook forms of civic, educational, and charitable work. ${ }^{43}$ What set the LWCS apart was an aspirational commitment to culture. ${ }^{44}$ 
In 1920, seeking to advance their standing, they worked in conjunction with their husbands and associated members of Boston's small black elite, including William L. Reed and Butler Wilson, to finance the purchase of a five-storey brownstone house to serve as their headquarters. ${ }^{45}$ The space was to double as a hub for community work but also as a communal meeting space for events, revues, and political functions. Seeking to attract elites in the city, the house was suitably finished. At the time of purchase, it was noted to have been adorned with 'marble fireplaces, French gold leaf chandeliers, a ballroom and library, fine iron work around the windows, massive mahogany staircases and doors, Corinthian columns, elaborate plaster work, huge venetian mirrors on the walls, silver doorknobs, and beautiful Victorian furniture'. ${ }^{46}$

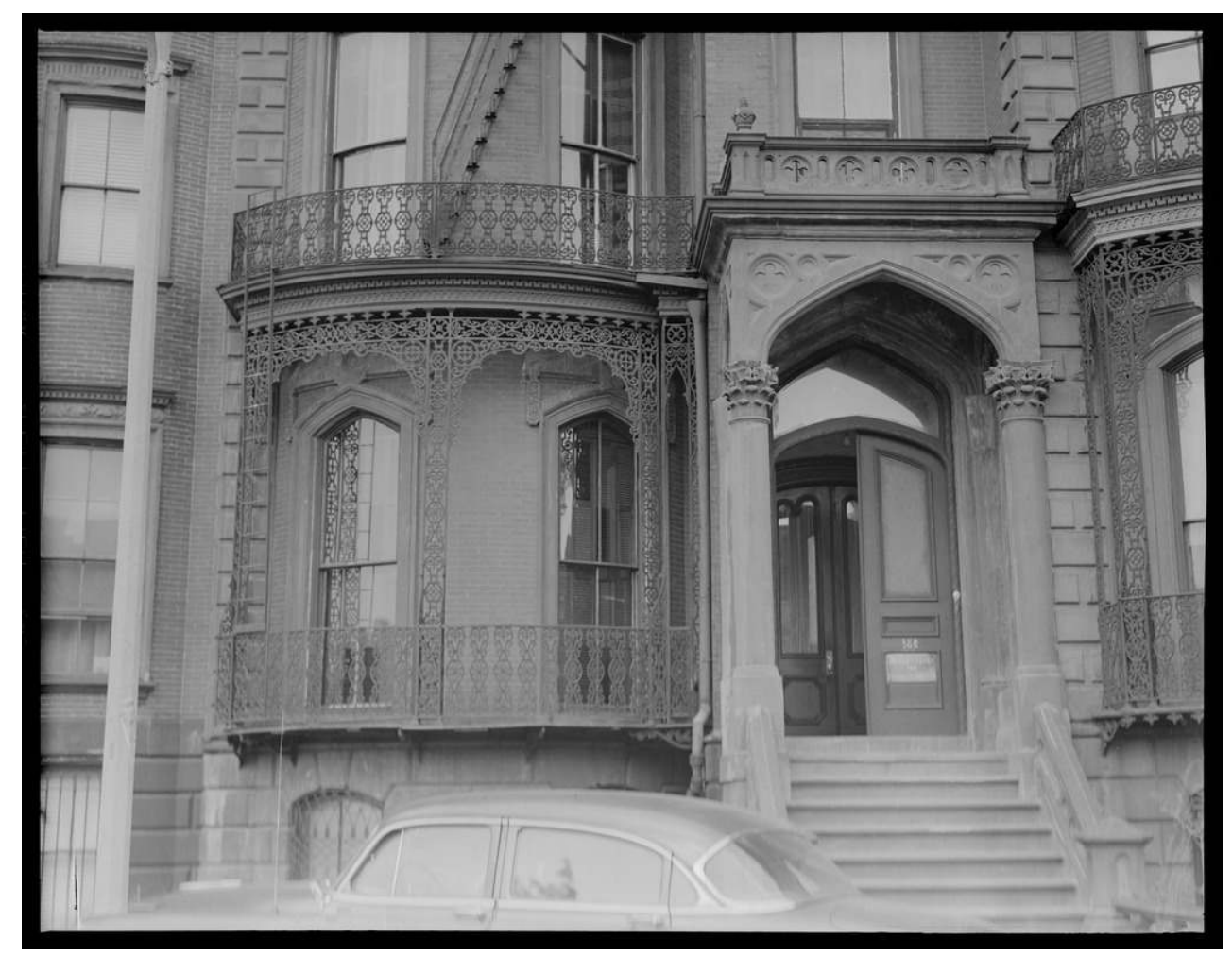

Ornamental iron lace work at 558 and 560 Massachusetts Ave., formerly 37 Chester Square $^{47}$

Beyond its aesthetic properties, the purchase was significant for historically symbolic reasons but also for its geographical position. Located at 558 Massachusetts Avenue, the house, also known as the Farewell Mansion after John Farewell, a wealthy (white) sea captain, shipping merchant, and avowed abolitionist, was an important part of Boston's black history. Built by William Rice Carnes in 1858, the mansion operated as an important stop on the Underground Railroad, a network of persons, including Harriet Tubman, that helped escaped slaves on their way to freedom during the period of abolition. ${ }^{48}$ Mary Ellen Snodgrass notes that, much like their abolitionist Brahmin counterparts of the time, Carnes and his wife, Martha B., consistently used their social prominence and wealth to aid the city's under-classes and oppressed. ${ }^{49}$

Geographically, the address lay just south of Huntington Avenue, described by Lorraine E. Roses and Crystal M. Flemming as the invisible demarcation between ethnic diversity and white homogeneity in early twentieth century Boston'. ${ }^{50}$ Huntington Avenue was home to many of Boston's Brahmin-led structures of secular and religious 
culture, including the Museum of Fine Art, Horticultural Hall, the Christian Science Mother Church, the Boston Opera House, and Symphony Hall..$^{51}$ As such, the LWCS's establishment of headquarters in the Brahmin locality served to support the groups integrationist philosophy. Its proximity to venerable white institutions overstepped Boston's well-defined traditional, cultural and social boundaries. ${ }^{52}$ At the formal opening of the Headquarters on March 20, 1920, members of the LWCS rubbed shoulders with Boston's elite. Guests included the former United States assistant attorney general, William H. Lewis; District Attorney, Joseph Pelletier; and three years before ascending to the United States Presidency, the then Governor of Massachusetts, Calvin Coolidge and his wife. ${ }^{53}$ This beginning set the tone for the League's approach thereafter. Cultural events were consistently held and aimed at noteworthy Brahmins and black Bostonians of esteem, including politicians, university chairmen, reverends, socialites, anti-racialists, and wealthy patrons. ${ }^{54}$ Academic lectures, musical revues, art exhibitions, social functions, and charity events ${ }^{55}$ regularly attracted large audiences - on average, in excess of two hundred guests per event. ${ }^{56}$

Performance and showcase events held by the LWCS, in Brahmin fashion, regularly extolled the musical refinement of composers such as Antonín Leopold Dvořák and Walter Damrosch. Members, in particular Maud Cuney Hare, criticised 'the ordinary songs of today written in ragtime set in execrable rhymes'.$^{57}$ In this sense, the League, who advocated the promotion of western classical-music appreciation, the kind firmly rooted in the study and practice of Mozart, as a way of uplift shared some sense of commonality with the white-led Boston media; for when blacks were seen to partake in the cultural preferences of whites, they were often accepted and on occasion, lauded. Black Spiritual singer, Paul Robeson, and composer and tenor singer, Laurence Brown both received praise from the Boston Globe for their contributions to music in the city, ${ }^{58}$ with the latter referred to as a 'unique figure in American life'. ${ }^{59}$

While blacks in neighbouring New York during 1919 pushed jazz towards the 'serious music' that Locke envisioned, the League dismissed it. Hare complained that it stifled 'the true musical instinct by turning away many of our talented young people from the persistent and continued study of good music'.$^{60}$ In this respect, Hare erred on the side of the widespread rejection of the music by America's white elite and leading cultural spokespersons, including music columnist for the Chicago Defender and bandleader, Dave Peyton. In his column, he condemned 'most jazz playing as rank musical ignorance, insisting that any trained musician could do it'. ${ }^{61}$ Again, the wider consensus in the LWCS was 'hokum music' lead race musicians to abandon concert hall instruments such as the violin for the louder and 'more vulgar' instruments of jazz. Robert Archey Woods adds:

Love of really good music does not yet exist to any great extent amongst local people. Their demands are fairly well satisfied by the street pianos, the band concerts, and the efforts of the poorly trained singer and musician such as are found in the cheapest amusement places. ${ }^{62}$

In the 1890s, white cultural wealth in Boston had extended to the South End, and several venues were opened that offered 'refined' musical entertainment to nonwhites. Amongst these venues were three first-class theatres: the Columbia, the Grand Opera House, and a smaller version of the latter, known simply as the Grand. ${ }^{63}$ By the close of 1897 , however, all three had 'failed'. ${ }^{64}$ Woods asserted in a 1898 Settlement Study that the collapse of these venues 'illustrates very forcibly the distinctness with which the district is set off from the so-called better parts of the town' ${ }^{65}$ However, the 
non-white population in the South End was relatively small and opening of three firstclass venues in close proximity to one another meant that limited ticket sales were shared. ${ }^{66}$ Moreover, wages were low in the area and poorer people were often priced out of the leisure of entertainment. ${ }^{67}$

This was compounded by the fact that residents of wealthier areas, in particular whites from the Back Bay and neighbouring suburbs were rarely induced to visit the South End to be entertained. ${ }^{68}$ This was a contrast to the act of 'slumming' - whites venturing into black neighbourhoods to be entertained - that occurred in northern cities two decades later, including Chicago and New York. Slummers thought black life exciting because it was 'primitive' and vital. Visiting the ghetto's haunts became the era's way to snub mainstream society, to be in the avant-garde. 'Jazz, the blues, Negro spirituals, all stimulate me enormously,' novelist Carl Van Vechten wrote H.L. Mencken in the summer of 1924. 'Doubtless, I shall discard them too in time'" In Boston, both apathy and a commitment to high-art and religious music stifled jazz and blues. ${ }^{69}$

On January 9, 1922, one of LWCS's figureheads, Maria L. Baldwin died from heart failure ${ }^{70}$ Poignantly, she collapsed during a significant address to members of the council of the Robert Gould Shaw House Association in Boston's Copley-Plaza. Eight weeks after her passing, the remaining members of the LWCS offered up a room at the Farewell Mansion for a public exhibition to honour her life and work. ${ }^{71}$ The exhibition, in the words of Ridley, Hare, and Trotter was a way to showcase the "collection and the preservation of material relating to the history of the Negro and those who have stood for justice to the Negro' ${ }^{72}$ To commemorate Baldwin's life and to promote the quest for black justice, prominent white speakers were invited, including clergymen, such as Samuel M. Crothers, and Pitt Dillingham; as well as the then President Emeritus of Harvard, Dr. Charles W. Elliot. ${ }^{73}$

The LWCS followed this in 1923 with the formal dedication of a library to Maria L. Baldwin at its headquarters. ${ }^{74}$ To mark the occasion, a bust of Anglo-American, John Brown (a participant in the Boston Tea Party, member of the Revolutionary Army, and prominent abolitionist) from the library of the late Colonel Thomas Wentworth Higginson, a proprietor of the Boston Athenaeum, was presented by his daughter; the Higginson's, in short, were Harvard educated Brahmins of substantial influence in Boston. ${ }^{75}$ The gesture was, thus, a symbolic one. Firstly, Brown had been a figure who embodied the commitment of whites to interracial progress during the abolition era. But more importantly, the transfer of the bust from the Higginson library to the newly established Baldwin library served as a tangible marker that indicated the developing link between the Brahmins and the LWCS.

This link was substantiated by the number of esteemed white guests in attendance at the dedication, including prominent Brahmins, church leaders, academics, and politicians. Among them was once again, Harvard President, Charles W. Eliot, and additionally, Boston Ethical Society Director, Harold K. Estabrook, Social Reformers and writers, Lucia Ade Mead and Cornelia J. Cannon, and President of the General Federation of Women's Clubs, Mrs Grace Morrison Poole. ${ }^{76}$ These guests were joined by significant black figures, including world-class collegiate athlete, lawyer, and politician, William H. Lewis. Guests were treated to a bibliographic tribute read by W. O. Goodell, and a performance of negro spirituals and hymns performed by the all black Vespers Quartet. 
37 By 1923, The LWCS were essentially part of a cultural hierarchy of distinction that effectively excluded the poor and working classes. Naturally, this approach to culture had implications. Wider black Boston rarely profited from the trickledown benefits of LWCS influence. Instead, the League's exclusivity mainly served to distance them somewhat from black-centric community groups - including the Women's Service Club (WSC), located at 464 Massachusetts Avenue - and civil rights organisations in the city. This resulted in what can loosely be defined as short-term black passivity. Hampered by limited support, and appeal, swathes of musicians, writers, artists, and more, including Jazz saxophonists Harry Carney and Johnny Hodges, and novelist Dorothy West migrated to more culturally affluent centres including New York, Chicago, and leading European cities such as Paris.

The LWCS were underpinned by a commitment to integration - i.e., bridging the gap between perceived 'good' black culture and the elite tastes of white Boston - served to legitimise the LWCS in the eyes of many Brahmins. But by opting to promote and present culture that was socially acceptable to the powerful and wealthy, the LWCS ultimately projected an outward indifference to the mainstream and popular artistic and expressive black forms of the time. Through fragmentation and siphoning talent, black Boston was reduced to a footnote in the grander narrative of the 1920s. Yet the paradoxical upside to the steady outward migration of its musicians, writers, artist and more is that the city was represented nationally, with individuals of cultural prominence enriching scenes and movements across America.

By the time jazz had made its way from the margins to the mainstream, the LWCS had all but exhausted the limited resources available to them, which grew thinner as more and more blacks, inspired by Louis Armstrong, Duke Ellington, and Sidney Bechet, turned to the instruments the League had dismissed a decade earlier and assisted in the growth and success of music at odds with the taste sensibilities of the LWCS. Ultimately, as national tastes changed and black mainstream art forms such as jazz became palatable and of wide appeal to black musicians and audience, the LWCS, unable to define their cultural field in Boston, struggled to sustain the cultural links that had been fashioned with leading Brahmins, and in time they consequently retreated full circle back into comfort work, with focus on providing lessons in mother craft. ${ }^{77}$

The Farewell Mansion, still owned by the LWCS, was declared a National Historic Site in 1974 by the Department of Interior and National Park Service. However, the once grand structure is now a victim to the cumulative assaults of wind, rain, snow, and gravity and it has since 2006 remained boarded, its façade crumbling and its ironworks rusting. A commemorative plaque affixed to the building declares that the LWCS 'has been dedicated to the cultural and educational advancement of Negro women'. While this is certainly true, their approach to advancement was not always the most profitable. Nonetheless, while the LWCS were not 'entrepreneurial' in the economic, Brahmin sense of the term, they intentionally constructed a defined professional and privileged black elite, and can, in this respect, be considered 'culturally entrepreneurial'. ${ }^{78}$ 


\section{NOTES}

1. Adelaide M. Cromwell, The Other Brahmins: Boston's Black Upper Class, 1750-1950 (University of Arkansas Press, 1994).

2. The League of Women for Community Service was formed in 1918.Throughout its existence, the League has fostered intellectual and artistic activity among Black Bostonians.

3. P. DiMaggio., Cultural entrepreneurship in nineteenth-century. Boston: the creation of an organizational base for high culture in America (London: Academic Press, 1982). 33-50.

4. William B. Gatewood, Aristocrats of Color: The Black Elite, 1880-1920 (Arkansas: University of Arkansas, 2000). 112.

5. Victoria Earle, 'The Woman's Era'. The Woman's Era. Volume 1. No. 2. May 1, 1894. 1

6. Alain Locke, The New Negro: An interpretation (New York: A. and C. Boni, 1925).

7. Boston Athenaeum, Reports - Boston Athenaeum (Boston: Boston Athenaeum, 1898), 9.

8. Boston Symphony Orchestra, 'Boston Symphony Orchestra: The Beginning', Boston Symphony Orchestra Concert Programs., Volume 86, 1967. 1062

9. Crystal M. Flemming, 'Black cultural capitalists: African-American elites and the organization of the arts in early twentieth century Boston'. Poetics. Volume 35, Issue 6. (December 2007). 368-387.

10. Paul DiMaggio and John Mohr, Cultural Capital, Educational Attainment, and Marital Selection. American Journal of Sociology. Vol. 90, No. 6. May 1985. pp. 1231-1261.

11. 'Help to make the world better' was the Woman's Era's motto. Josephine St. Pierre Ruffin, 'The Woman's Era Club'. The Woman's Era. Volume 1. 1894. an electronic edition. Available:

http://womenwriters.digitalscholarship.emory.edu/advocacy/content.php?

level=div\&id=era1_we.1.01.03.08\&document=era1. Accessed: November 29, 2018.

12. W. E. B. Du Bois, The Philadelphia Negro: A Social Study (Pennsylvania: University of Pennsylvania Press, 2010) pp. 124-5.

13. Ibid.

14. Adelaide M. Cromwell, The Other Brahmins: Boston's Black Upper Class, 1750-1950 (University of Arkansas Press, 1994).

15. William B. Gatewood, Aristocrats of Color: The Black Elite, 1880 - 1920 (Arkansas: University of Arkansas Press, 1990).

16. No Author Attributed, 'Assembles Papers of Famed Dad', The Pittsburgh Courier. January 14, 1939. 3.

17. William Edward Burghardt du Bois, The Crisis, Volumes 81-82. (Crisis Publishing Company, 1974), 347.

18. William Wells Brown, The Rising Son, Or, The Antecedents and Advancement of the Colored Race (A. G. Brown \& Company, 1882) 391.

19. Quinquennial Catalogue of the Officers and Graduates of Harvard University (Boston: Harvard University, 1900).

20. Stephen R. Fox suggests that Trotter lived in a single room in College House, the cheapest student dormitory and paid for most of his education himself. Stephen R. Fox, The guardian of Boston: William Monroe Trotter (Boston: Athenaeum, 1970), 17.

21. Department of Commerce: Bureau of the Census, Fourteenth Census of the United States Taken in the Year 1920. Volume III Population - Age for Cities and Towns of 10,000 or More 1920. Page 438. Despite its small size, the black community in Boston produced the Hub in the 1880s and the Courant in the 1890s. This tied in with more broadly race-related activities including the 
Colored National League and the Citizens' Equal Rights Association which sought to safeguard the Fourteenth and Fifteenth Amendments, known as the Civil Rights Amendments.

22. W. E. B. Du Bois, Du Bois on Education (Maryland: Rowman Altamira, 2002) 37.

23. W.E.B. Du Bois, 'Papers: Special Collections \& University Archives University of Massachusetts, Amherst, Massachusetts', Journal of Pan African Studies. October 2017. Vol.10, p.395. 24. Victoria Earl, 'The Woman's Era, The Woman's Era. Volume 1. No. 2 (May 1, 1894.), p 1.

25. Josephine St. Pierre Ruffin, The Woman's Era Club'. The Woman's Era, Volume 1, an electronic edition. Saturday, March 24 1894. Available: http://womenwriters.digitalscholarship.emory.edu/ advocacy/content.php?level=div\&id=era1_we.1.01.03.08\&document=era1. Accessed: November 29, 2018.

26. Maude T. Jenkins, 'Letters'. The Women's Review of Books. Vol. 16, No. 12. September 1999. 5.

27. Josephine St. Pierre Ruffin, 'Tourgee in Boston'. The Woman's Era, Volume 1. 1894.

28. Ibid.

29. An example of its comfort services was the formation of a sewing circle to aid St. Monica's Home, a hospital for colored women. Adelaide M. Cromwell, The Other Brahmins: Boston's Black Upper Class, 1750-1950 (University of Arkansas Press, 1994). 78.

30. Author Unknown, Colored Women Open Clubhouse. Boston Daily Globe. May 21, 1920. 48.

31. Mary Church Terrell in Beverly Washington Jones, Quest for equality: the life and writings of Mary Eliza Church Terrell, 1863-1954 (New York: Carlson Publishing, 1990). 154.

32. Involvement in the Boston School Committee highlighted a developing rift in the city between Irish women, represented by Julia Duff, and Yankee women, represented by Emily Fifield, over control of the city's School Committee, the first Massachusetts forum in which women were allowed political representation. Author Unknown, 'Mrs. Duff Biffs School Board', The Atlanta Constitution. November 16, 1902. p. 7

33. Katie Canon, Black Womanist Ethics (California: Wipf and Stock Publishers, 2006).

34. In 1896 when the National Federation of Afro-American Women in Washington D.C., merged with the Colored Women's League of Washington, D.C., to form the National Association of Colored Women, Pierre Ruffin served as its first vice-president. She placed herself at the helm of the largest federation of local black women's clubs.

35. Darlene Clark Hine, William C. Hine, Stanley Harrold, The African-American odyssey (New Jersey: Prentice Hall, 2002), 372.

36. Members of the Women's Era Club developed ties to the Equal Rights League, the Massachusetts State Union of Women's Clubs, the Northeastern Federation of Coloured Women's Clubs, and the Republic Ladies Auxiliary. U.S. Government. Superintendent of Documents, Catalogue of United States Public Documents, Issues 25-36 (Washington: U.S. Government Printing Office, 1897).

37. In addition to working as an on-off columnist for W.E.B Du Bois' the Crisis, while living in Texas, she also served as the director of music at the Deaf, Dumb, and Blind Institute (1897) and at Prairie View State College (1903-1904). Cuney Hare relocated to Boston in 1906, following her marriage to William Hare. Karen Kossie-Chernyshev, Recovering Five Generations Hence: The Life and Writing of Lillian Jones Horace (Texas: Texas A\&M University Press, 2013), 143.

38. Madeline G. Allison, The Horizon, The Crisis. April 1922. 271.

39. Nancy Glidden Coffey, The Story of Edgewater House, 1910-2016 (Beverly, Mass: Lulu.com, 2016). 26.

40. No Author Attributed, 'The War-Work Fund'. The Youth's Companion, Volume 92, Part 2. 530.

41. The League of Women for Community Service: Celebrating More Than 90 Years of Service to the Community (Home). Available: http://leagueofwomen.org. Accessed: 3 July, 2014. 
42. Author unknown, 'Colored Women Open Clubhouse: Soup Kitchen Part of Its Community Service'. Boston Daily Globe. March 21, 1920. P. 46.

43. The League of Women for Community Service: Celebrating More Than 90 Years of Service to the Community (Home). Available: http://leagueofwomen.org. Accessed: 3 July, 2014.

44. Ibid.

45. Author Unknown, $\$ 4000$ Subscribed for League Home, Boston Herald. Published: December 8 , 1919. p. 13.

46. Lorraine Roses, 'A Tale of Two Womens' Organizations' Boston Black History. February 22, 2006. Accessed December 1. Available:

47. John Leslie, August 1, 1956. Ornamental iron lace work at 558 and 560 Massachusetts Ave., formerly 37 Chester Square. Photographs: Film Negatives - Black and White. Accessed: November 11, 2018. Available: https://www.digitalcommonwealth.org/search/commonwealth:8c97mt16w

48. Nancy C. Curtis, Black Heritage Sites: An African American Odyssey and Finder's Guide (Washington: American Library Association, 1996), 302.

49. In the mid-twentieth century, the mansion sheltered a struggling music student, Coretta Scott, who worked as a domestic assistant until her marriage to Martin Luther King, Jr., in 1953.

50. Crystal M. Flemming, Lorraine E. Roses, 'Black cultural capitalists: African-American elites and the organization of the arts in early twentieth century Boston', Poetics 35 (2007), 374.

51. Boston Athenaeum, Reports - Boston Athenaeum (Boston: Boston Athenaeum, 1898), 9.

52. The LWCS distanced themselves not just from other black organisations in their vicinity, but also a concentration of speakeasies cum bordellos on Huntington Avenue and local entertainment venues of a questionable nature. Whereas, the compacted Harlem scene of New York can be seen to have used bordellos, jazz clubs, bars, and speakeasies to cultivate an innovative and shared black voice, in Boston there was no such concentration of black culture.

53. Author Unknown, 'Governor and Wife at Formal Opening', The Boston Herald. Published: March 20, 1920. 11 .

54. President Emeritus Charles W. Elliot, Reverend Samuel M. Crothers, and William H. Lewis are but three examples. Author Unknown, 'Members of the League of Women for Community Service', The Boston Herald. Published: March 12, 1922. 5.

55. Author Unknown, 'Members of the League of Women for Community Service', The Boston Herald. Published: March 12, 1922. 5.

56. Author Unknown, 'Soup Kitchen Remains Open at the Demand of 200 Boys', Boston Sunday Herald. Published: June 13, 1920. B4E.

57. Maud Cuney Hare in Lorenzo Thomas Don't Deny My Name: Words and Music and the Black Intellectual Tradition (Michigan: University of Michigan Press, 2008), 101.

58. No Author Attributed., 'Negro Singer Has Won Honours: Paul Robeson, who will sing here Next Sunday, Has Had a Remarkable Record in and out of College, Boston Daily Globe. Published: March 7, 1926. P. A53.

59. Ibid.

60. Maud Cuney Hare, 'Girls Page for January'. The Youth's Companion. Volume 85, Part 1. 14.

61. Randle Sandke, Where the Dark and the Light Folks Meet: Race and Mythology, Politics, and Business of Jazz. (New York: Scarecrow Press, 2010). 95.

62. The Residents and Associates of the South End House, Edited by Robert Archey Woods, The City Wilderness: A Settlement Study (Cambridge, MA: The Riverside Press, 1898), 185-7.

63. The Residents and Associates of the South End House, Edited by Robert Archey Woods, The City Wilderness: A Settlement Study (Cambridge, MA: The Riverside Press, 1898), 185-7. 
64. Ibid.

65. Ibid.

66. Ibid., 184-90.

67. The Residents and Associates of the South End House, Edited by Robert Archey Woods, The City Wilderness: A Settlement Study (Cambridge, MA: The Riverside Press, 1898), 184.

68. Ibid., 184-6.

69. David L. Lewis, When Harlem was in Vogue (New York: Vintage Books, 1982). 98.

70. Author Unknown, 'Maria Baldwin Dies Suddenly', Boston Daily Globe, Published: January 10, 1922. Page 1

71. Author Unknown, 'Exhibition at 558 Massachusetts Avenue', Boston Herald. Published: March 12, 1922. p. C5.

72. Ibid., p. C5

73. Author Unknown, 'Dedicates Library to Maria Baldwin', Boston Herald. Published: December 21, 1923. p. 14.

74. Author Unknown, 'Maria Baldwin Library Dedicated at Exercise', Boston Daily Globe. December 21, 1923. p. 7.

75. J. Lection, 'The Athenaeum' The Athenaeum: Journal of Literature, Science, and the Fine Arts (July to December 1862) p. 259.

76. Author Unknown, 'Exhibition at 558 Massachusetts Avenue', Boston Herald. Published: March 12, 1922. p. C5

77. During the 1940s and 1950s the organisation housed dozens of women at 558 Mass Ave while they attended colleges in Boston. One notable woman was Coretta Scott King, who resided at the League while attending the New England Conservatory of Music and while dating Martin Luther King Jr.

78. Ibid.

\section{AUTHOR}

\section{CRAIG DOUGHTY}

In June 2017, Dr Craig Doughty completed a PhD thesis entitled 'Constructing a history from fragments: jazz and voice in Boston, Massachusetts, circa 1919 - 1929'. This work applied an interdisciplinary methodological approach that incorporated musicology and subaltern studies. The focus was on the appropriation of jazz music produced by underrepresented blacks in Boston during the period into a form of protest dialogue. This work builds on his previous research that has focused on the social, cultural, and economic dynamics of Latin America, particularly Chile and Venezuela, and the ways in which underrepresented and oppressed peoples utilised cultural forms of expression as a means of establishing voice when conventional forms of dialogue were no longer possible. Dr Doughty's current research, entitled 'Can the Subaltern Play' seeks to broaden the scope of his previous research, notably his $\mathrm{PhD}$ thesis by focusing on jazz in Boston from 1910 to 1949. In doing so, this research provides a suitable opportunity to advance $\mathrm{Dr}$ Doughty's proposed methodological approaches to historical reconstruction over a longer period, 
and in doing so ascertain to what extent the social and cultural dynamics of black Boston changed from the turn of the century to its mid-point and the causes for these changes. 